\title{
Correction to: Masur-Veech volumes and intersection theory on moduli spaces of Abelian differentials
}

\author{
Dawei Chen ${ }^{1}$ - Martin Möller ${ }^{2}$. \\ Adrien Sauvaget ${ }^{3}$. Don Zagier ${ }^{4}$
}

Published online: 10 June 2021

(C) The Author(s) 2021

\section{Correction to: Invent. Math. (2020) 222:283-373 https://doi.org/10.1007/s00222-020-00969-4}

The article Masur-Veech volumes and intersection theory on moduli spaces of Abelian differentials, written by Dawei Chen, Martin Möller, Adrien Sauvaget and Don Zagier, was originally published Online First without Open Access. After publication in volume 222, issue 1, page 283-373 the authors decided to opt for Open Choice and to make the article an Open Access publication. Therefore, the copyright of the article has been changed to () The Author(s)

The original article can be found online at https://doi.org/10.1007/s00222-020-00969-4.

$凶$ Martin Möller

moeller@math.uni-frankfurt.de

Dawei Chen

dawei.chen@bc.edu

Adrien Sauvaget

a.c.b.sauvaget@uu.nl; adrien.sauvaget1@u-cergy.fr

Don Zagier

donzagier@mpim-bonn.mpg.de

1 Department of Mathematics, Boston College, Chestnut Hill, MA, USA

2 Institut für Mathematik, Goethe-Universität Frankfurt, Frankfurt am Main, Germany

3 Laboratoire de Mathématiques AGM, UMR 8088 du CNRS, Université de Cergy-Pontoise, Cergy-Pontoise Cedex, France

4 MPIM Bonn, Bonn, Germany 
2020 and the article is forthwith distributed under the terms of the Creative Commons Attribution 4.0 International License, which permits use, sharing, adaptation, distribution and reproduction in any medium or format, as long as you give appropriate credit to the original author(s) and the source, provide a link to the Creative Commons licence, and indicate if changes were made. The images or other third party material in this article are included in the article's Creative Commons licence, unless indicated otherwise in a credit line to the material. If material is not included in the article's Creative Commons licence and your intended use is not permitted by statutory regulation or exceeds the permitted use, you will need to obtain permission directly from the copyright holder.To view a copy of this licence, visit http://creativecommons. org/licenses/by/4.0/.

Open Access funding enabled and organized by Projekt DEAL.

The original article has been corrected. We apologise for any inconvenience caused to our readers.

Open Access This article is licensed under a Creative Commons Attribution 4.0 International License, which permits use, sharing, adaptation, distribution and reproduction in any medium or format, as long as you give appropriate credit to the original author(s) and the source, provide a link to the Creative Commons licence, and indicate if changes were made. The images or other third party material in this article are included in the article's Creative Commons licence, unless indicated otherwise in a credit line to the material. If material is not included in the article's Creative Commons licence and your intended use is not permitted by statutory regulation or exceeds the permitted use, you will need to obtain permission directly from the copyright holder. To view a copy of this licence, visit http://creativecommons.org/licenses/by/4.0/.

Publisher's Note Springer Nature remains neutral with regard to jurisdictional claims in published maps and institutional affiliations. 